\title{
Batch and column studies on heavy metal removal using a local zeolitic tuff
}

\author{
Özge Can *, Devrim Balköse, Semra Ülkü \\ Izmir Institute of Technology, Department of Chemical Engineering, Gulbahce Koyu, 35430 Urla, Izmir, Turkey
}

\section{A R T I C L E I N F O}

\section{Article history:}

Received 15 October 2009

Received in revised form 6 April 2010

Accepted 22 April 2010

Available online 14 May 2010

\section{Keywords:}

Ion exchange

Clinoptilolite

Copper

Nickel

Cobalt

Langmuir

\begin{abstract}
A B S T R A C T
Ion exchange is considered to be one of the most cost effective methods if low cost ion exchangers such as natural zeolites are used in waste water treatment. In this study, a zeolitic tuff rich in clinoptilolite from Gördes Manisa Turkey was examined to evaluate its ion exchange performance for the removal of copper, nickel and cobalt ions from metal (II) nitrate solutions at various concentrations by performing both batch and packed column experiments. A clinoptilolite tuff with purity around $60 \%$ was used in ion exchange experiments. Copper, nickel and cobalt exchange capacities of the tuff were determined as $8.3 \mathrm{mg}$ (0.26 meq) $\mathrm{Cu}^{2+} / \mathrm{g}, 6.6 \mathrm{mg}(0.23 \mathrm{meq}) \mathrm{Ni}^{2+} / \mathrm{g}$ and $4.5 \mathrm{mg}(0.15 \mathrm{meq}) \mathrm{Co}^{2+} / \mathrm{g}$, respectively. The equilibrium behavior of the system was best described by classical Langmuir model. The experimental breakthrough curves from the column experiments were fitted to solid diffusion control model. The study showed that efficient metal ion removal can be done by using the local clinoptilolite rich tuff.
\end{abstract}

(c) 2010 Elsevier B.V. All rights reserved.

\section{Introduction}

Industrial waste waters frequently contain high levels of heavy metals and efficient treatment is needed as it is crucial to avoid water pollution due to increasing social and economic importance of environmental conservation. Heavy metal pollution often results from industrial use of organic compounds containing metal additives in the petroleum and organic chemical industries, petroleum refining, pulp industries and fertilizers, iron and steel manufacturing plants [1]. The zeolite group includes more than 40 naturally occurring species, and is the largest group of the minerals among the silicates [2]. Clinoptilolite is probably the most abundant zeolite in nature because of its wide geographic distribution and large size of deposits. Characteristic clinoptilolite rocks consist of $60-90 \%$ clinoptilolite with the remaining being mainly feldspars, clays, glass, and quartz [3]. Natural zeolites with approximately $70-80 \%$ clinoptilolite content are often used in technological applications [4]. Ion exchange is considered to be one of the most cost effective methods if low cost ion exchangers such as natural zeolites are used. Removal of $\mathrm{Ni}(\mathrm{II})$ ions [5-7], $\mathrm{Cu}$ (II) ions [7-9], $\mathrm{Cd}$ (III) [6,9], $\mathrm{Pb}$ (II) [9] and $\mathrm{Cd}$ (II) [6,9] by clinoptilolite minerals from different origins were investigated by previous researchers.

In this study, ion exchange performance of a zeolitic tuff from Gördes Turkey for the removal of copper, nickel and cobalt ions by

\footnotetext{
* Corresponding author. University of Delaware, Department of Chemical Engineering, 150 Academy Street, Newark, DE 19716, United States. Tel.: + 1302831 6851; fax: + 1302 8311048.

E-mail address: ozgecan@udel.edu (Ö. Can).
}

performing both batch and packed column experiments was aimed to be investigated.

\section{Materials and methods}

\subsection{Zeolitic tuff}

Natural zeolite sample was taken representatively from Gördes/ Manisa region, Enli Madencilik A.Ş. Approximately $500 \mathrm{~kg}$ samples were collected and then simultaneously divided into four groups until the desired amount of samples were obtained. For characterization, these samples were firstly crushed into $1-2 \mathrm{~cm}$ range of particle size and then into $<2 \mathrm{~mm}$ size range with a jaw crusher (Fritsch, Pulverisette 1). Particles smaller than $2 \mathrm{~mm}$ size were then wet sieved into five groups namely; >1.7 mm, $425 \mu \mathrm{m}-1.7 \mathrm{~mm}, 106-425 \mu \mathrm{m}, 25-$ $106 \mu \mathrm{m}$ and finally smaller than $25 \mu \mathrm{m}$. Particles smaller than $25 \mu \mathrm{m}$ were mixed with water and settled particles under gravity were called "very fine" and the ones dispersed in water are called "ultrafine" particles. Afterwards, the solution containing ultrafine particles were first separated from the precipitate by overflowing and then centrifuged. After wet sieving process, all zeolite fractions were dried at $105{ }^{\circ} \mathrm{C}$ overnight. The chemical composition of the tuff was reported by Akdeniz and Ulku as $69.89 \% \mathrm{SiO}_{2}, 11.21 \% \mathrm{Al}_{2} \mathrm{O}_{3}, 1.15 \%$ $\mathrm{Fe}_{2} \mathrm{O}_{3}, 5.48 \% \mathrm{~K}_{2} \mathrm{O}, 1.89 \% \mathrm{CaO}, 1.56 \% \mathrm{Na}_{2} \mathrm{O}, 0.22 \% \mathrm{MgO}$ and $8.6 \% \mathrm{H}_{2} \mathrm{O}$ [10].

Standard materials used for quantitative analyses were obtained from Mineral Research, Clarkson, New York with +90\% pure, clinoptilolite, IDA (\# 27031, Castle Creek, Idaho) and CAL (\# 27023, Hector, California). Relative Intensity Ratio (RIR) standard and sample mixtures were prepared by mixing $1.0 \mu \mathrm{m} \alpha$-alumina powder 
(corundum) to each mineral standard and sample in a 50:50 ratio by weight. The X-ray diffraction diagrams of the mixtures were also obtained.

Powder X-ray diffraction diagram of the samples were taken using Philips X'pert Pro employing the $\mathrm{Cu} \mathrm{K} \mathrm{K}_{\alpha}$ radiation of power settings of $30 \mathrm{kV}$ and $30 \mathrm{~mA}$. Data were collected using a step size of $0.02^{\circ} 2 \theta$ and a count time of $2 \mathrm{~s} /$ step. Several discrete $2 \theta$ ranges between 5 and $40^{\circ}$ $2 \theta$ were used to measure only the reflections of interest.

\subsection{Preparation of samples for ion exchange}

Tuffs were crushed smaller than $2 \mathrm{~mm}$ size by using a jaw crusher (Fritsch, Pulverisette 1). Crushed samples were sieved by using Retsch Sieve set and fraction between 0.85 and $2.0 \mathrm{~mm}$ aperture sieves were used in batch and packed column experiments. The fractionated clinoptilolite samples were dried in the oven at $110{ }^{\circ} \mathrm{C}$ and kept in a desiccator until they were needed for ion exchange experiments without any further pretreatment.

\subsection{Batch kinetic and equilibrium experiments}

Equilibrium behavior of the system and the effect of initial metal ion concentration were investigated for the tuff by running ion exchange experiments twice for the same conditions using fresh tuff samples. Three transition elements of the periodic table ( $\mathrm{Co}, \mathrm{Ni}$ and $\mathrm{Cu}$ ) having atomic numbers 27,28 and 29 were chosen to be studied for ion exchange with the tuff. Their discharge limits in waste water are lower than $5 \mathrm{mg} \mathrm{dm}^{-3}$ in many countries.

Single solutions of $\mathrm{Cu}\left(\mathrm{NO}_{3}\right)_{2}, \mathrm{Ni}\left(\mathrm{NO}_{3}\right)_{2}$ and $\mathrm{Co}\left(\mathrm{NO}_{3}\right)_{2}$ with different concentrations were prepared using deionized water. Then, $1 \mathrm{~g}$ of clinoptilolite sample was placed in volumetric flasks having $100 \mathrm{~cm}^{3}$ of salt solutions and shaken at $130 \mathrm{rpm}, 30^{\circ} \mathrm{C}$ in water bath. For five days period, $1 \mathrm{~cm}^{3}$ samples were taken at specific time intervals and analyzed until no further metal uptake from zeolite sample was observed (data not shown). However, for each set of experiment, the number of solutions prepared for the sampling stage was equal to the number of samples taken to maintain the solid to solution ratio constant. Finally, solutions were analyzed using Inductively Coupled PlasmaAtomic Emission Spectrometry (Axial ICP-OES 96, Varian Liberty Series).

\subsection{Packed column studies}

In the fixed bed studies, ion exchange experiments were carried out in Pyrex ion exchange column of $30 \mathrm{~cm}$ height and $1.5 \mathrm{~cm}$ inner diameter. The feed was introduced to the system using a Cole-Parmer diaphragm pump (CZ-76 302-05) in up-flow mode with adjustable flow rate between 1 and $50 \mathrm{~cm}^{3} / \mathrm{min}$. In these experiments, samples were collected at specific time intervals by using an automatic fraction collector (Atto Biocollector, AC-5750). Effluent concentrations of the samples were analyzed using ICP-OES.

As a result of these studies, ion exchange performance of the tuff for the single solutions of the different heavy metal ions $\left(\mathrm{Cu}^{2+}, \mathrm{Ni}^{2+}\right.$ and $\mathrm{Co}^{2+}$ ) as well as the effect of packing height for $\mathrm{Cu}(\mathrm{II})$ ions was determined. During the studies, the stock solution pumped through the column was kept in a water bath at $30 \pm 1^{\circ} \mathrm{C}$. The column temperature was controlled by flowing solution through the column. The experimental column parameters are given in Tables 1 and 2.

\section{Table 1}

Process parameters to investigate the column performance of the zeolitic tuff for single solutions of different metal ions.

\begin{tabular}{llll}
\hline Metal & $\begin{array}{l}\text { Initial conc. } \\
{\left[\mathrm{mg} / \mathrm{dm}^{3}\right]}\end{array}$ & $\begin{array}{l}\text { Flow rate } \\
{\left[\mathrm{cm}^{3} / \mathrm{min}\right]}\end{array}$ & $\begin{array}{l}\text { Packing height } \\
{[\mathrm{cm}]}\end{array}$ \\
\hline $\mathrm{Cu}^{2+}, \mathrm{Ni}^{2+}, \mathrm{Co}^{2+}$ & 150 & 3.8 & 22 \\
\hline
\end{tabular}

\subsection{Analyses of the solutions}

After ion exchange experiments, stock solutions of $10 \%(\mathrm{w} / \mathrm{w})$ of nitric acid together with the sample solutions taken from the fixed bed experiments were prepared for ICP analyses. $10 \mathrm{~cm}^{3}$ of sample solutions were diluted to $100 \mathrm{~cm}^{3}$ by adding deionized water to the mixture containing $1 \% \mathrm{w} / \mathrm{w}$ of $\mathrm{HNO}_{3}$.

\subsection{Modeling of batch and column experiments}

Equilibrium behavior is usually described in terms of equilibrium isotherms, which depend on the system temperature, solution concentration, $\mathrm{pH}$ and mineral type. Langmuir model has been extensively used for ion exchange in tuffs rich in clinoptilolite by previous investigators [5,6,9]. Even though one of the assumptions of the Langmuir model that requires adsorption sites with equal energies was not satisfied, since $\mathrm{Na}^{+}, \mathrm{K}^{+}, \mathrm{Ca}^{2+}$ and $\mathrm{Mg}^{2+}$ ions were exchanged with $\mathrm{Cu}^{2+}, \mathrm{Co}^{2+}$ and $\mathrm{Ni}^{2+}$ ions in the present study, this model (Eq. (1)) was used to describe the equilibrium behavior of the system as an oversimplification of the process [13].

$\frac{q}{q_{\max }}=\frac{b C}{1+b C}$

Where, $q$ is the amount of solute in the solid phase, $q_{\max }$ is the maximum amount of solute in the solid phase, $C$ is the concentration in the solution phase and $b$ is the Langmuir equilibrium constant.

The effective diffusion coefficient of $\mathrm{Cu}$ (II) ions in zeolitic tuff particles was determined as $6.18 \times 10^{-11} \mathrm{~m}^{2} \mathrm{~s}^{-1}$ from kinetic data [11]. Biot number (Bi) described in Eq. (2) was used to understand whether mass transfer was solid diffusion or external fluid film controlled. Biot numbers greater than 3 indicate that solid diffusion controls the mass transfer [12].

$B i=k d_{\mathrm{p}} / 3 D$

Where $d_{\mathrm{p}}, k$ and $D$ are the average particle size, external fluid film mass transfer coefficient and $D$ effective diffusion coefficient in solid, respectively. $k$ was found from using Eq. (3) and for the lowest flow rate $1.87 \mathrm{~cm}^{3} / \mathrm{min}$ as $1.47 \times 10^{-5} \mathrm{~cm} / \mathrm{s}$ [3].

$S h=(1.09 / \varepsilon) R e^{0.33} S c^{0.33}$

Where Sh, Re and Sc represent Sherwood number, Reynolds number and Schmidth number, respectively.

Biot number was found as 4.1 for the system indicating that solid diffusion controls the mass transfer.

Analytical solution of breakthrough curves for the limiting cases of solid diffusion control was solved by Cooper [13].

In this model, linear rate solid film equation is represented as

$\frac{\partial \bar{q}}{\partial t}=k\left(q_{\mathrm{s}}-\bar{q}\right)$

Where, $q_{\mathrm{s}}$ and $\overline{\mathrm{q}}$ are the sorbate concentration at saturation limit and the value of sorbate concentration averaged over crystal, respectively.

Table 2

Copper exchange parameters to investigate the effect of packing height using the zeolitic tuff.

\begin{tabular}{lccc}
\hline$C_{\mathrm{o}}\left[\mathrm{mg} / \mathrm{dm}^{3}\right]$ & 200 & 200 & 200 \\
Flow rate $\left[\mathrm{cm}^{3} / \mathrm{min}\right]$ & 1.87 & 1.87 & 1.87 \\
Bed height $[\mathrm{cm}]$ & 12.5 & 18.75 & 25 \\
Amount of zeolite $[\mathrm{g}]$ & 14 & 20 & 27 \\
\hline
\end{tabular}


According to Cooper model, solution for breakthrough curve is given by,

$\frac{C}{C_{0}}=1-\xi e^{-\tau}, \quad \xi \leq 1.0$

$\frac{C}{C_{0}}=1-e^{\xi-\tau-1}, \quad 1 \leq \xi \leq 1+\tau$

$\frac{C}{C_{0}}=0, \quad \xi \geq 1+\tau$

$\tau=k\left(t-\frac{z}{v}\right)$ and $\xi=\frac{k K z}{v}\left(\frac{1-\varepsilon}{\varepsilon}\right)$

Where, $\tau$ is the dimensionless time, $\xi$ is the dimensionless column length, $v$ is the interstitial velocity, $\varepsilon$ is the bed voidage, $k$ is the overall effective mass transfer coefficient $\left(\mathrm{s}^{-1}\right), t$ is time and $z$ is the packing height.

This model was used by approximating the Langmuir adsorption isotherm of the zeolite used in the present study to irreversible isotherm. Thus, the Cooper model would give a rough estimate about the actual behavior of the system.

\section{Results and discussion}

\subsection{Characterization studies}

The X-ray diffraction diagram of different fractions of the zeolitic tuff shown in Fig. 1 indicated that it contained clinoptilolite. There are not much intensity differences of diffraction peaks for different particle sizes as seen in Fig. 1.

Using relative intensity ratio (RIR) method [10] the purity of the tuff was determined. The RIR method requires that reference intensity ratios have been measured for one or more reflection for each phase to be analyzed. The reference intensity ratio is defined as the intensity of the peak of interest for a given phase divided by the intensity of a peak from a standard in a 50:50 mixture with corundum. RIR method indicated that the tuff contained $60 \%$ clinoptilolite [14] by using Idaho and California standards. The other constituents of the tuff were determined qualitatively by using the search match program of Philips X'pert Pro X-ray diffractometer. According to this, clay and quartz were the other major constituents of the tuff.

\subsection{Ion exchange}

Ion exchange capacity of the tuff towards the ions studied was determined to be the greatest for $\mathrm{Cu}^{2+}$ and smallest for the $\mathrm{Co}^{2+}$ ions. In Fig. 2, ion exchange isotherms of these cations were constructed for the zeolitic tuff with the corresponding Langmuir model in terms of species concentration in the solid phase as a function of its value in solution.

Langmuir model described the equilibrium behavior of all systems with a regression coefficient of 0.99 . The Langmuir constant, $q_{\max }$, in Eq. (1) was $8.3 \mathrm{mg}(0.26 \mathrm{meq}) \mathrm{Cu}^{2+} / \mathrm{g}, 6.6 \mathrm{mg}(0.23 \mathrm{meq}) \mathrm{Ni}^{2+} / \mathrm{g}$ and $4.5 \mathrm{mg}$ ( $0.15 \mathrm{meq}) \mathrm{Co}^{2+} / \mathrm{g}$ and constant $b$ was found to be 0.05 , 0.30 and 0.19 for copper, nickel and cobalt ions, respectively. Based on these results, the following general trend for ion exchange capacity series was obtained: $\mathrm{Cu}^{2+}>\mathrm{Ni}^{2+}>\mathrm{CO}^{2+}$. Hydrated radii of $\mathrm{Ni}^{2+}$, $\mathrm{Cu}^{2+}$ and $\mathrm{Co}^{2+}$ ions were reported as $0.404,0.419$ and $0.423 \mathrm{~nm}$, respectively [15]. Clinoptilolite has a two-dimensional pore system with three different channels having pore openings of $0.26 \times 0.47$, $0.30 \times 0.76$ and $0.33 \times 0.46 \mathrm{~nm}$, respectively [16]. Thus the ions should diffuse as ions leaving their hydration water molecules in solution and forming more stable compounds with functional groups in pores of the zeolites by exchanging with $\mathrm{Na}^{+}, \mathrm{Ca}^{+2}$ and $\mathrm{Mg}^{+2}$ ions. The contribution of the other minerals such as quartz and clay present in zeolitic tuff to ion exchange should also be taken into consideration. Clay minerals also are used in removal of heavy metal ions from waste waters. The monolayer capacity of a clay sample has been reported to be in the range of 48.54 to 60.98 and 58.48 to $69.93 \mathrm{mg} / \mathrm{g}$ for $\mathrm{Ni}^{+2}$ and $\mathrm{Cu}^{+2}$ ions, respectively [17]. Selectivity to $\mathrm{Cu}^{+2}$ to $\mathrm{Ni}^{+2}$ was explained in terms of higher stability of $\mathrm{Cu}^{+2}$ complexes, lower solubility of $\mathrm{Cu}(\mathrm{OH})_{2}$ than $\mathrm{Ni}(\mathrm{OH})_{2}$ lower hydrolysis constant $\left(\mathrm{pK}_{\mathrm{h}}\right)$ of $\mathrm{Cu}^{+2}$ than $\mathrm{Ni}^{+2}$ [17].

The ion exchange capacities for $\mathrm{Cu}^{2+}$ determined in this work fall within the corresponding range reported in the literature [18]. On the contrary, some studies showed that the ion exchange capacities determined using natural clinoptilolite were lower than the values indicated in this study $[19,20]$. In addition, studies performed by Nikashina et al. [21], Guangsheng et al. [22] and Langella et al. [23] showed that the ion exchange capacities determined using sodium form of clinoptilolite were higher. The reason for obtaining such results is due to the usage of different zeolitic tuffs and different modified forms of natural material.

The breakthrough time was defined as the time when the outlet flow has reached $5 \mathrm{mg} / \mathrm{g}$ metal ion concentration. It was 250,119 and $118 \mathrm{~min}$ for $\mathrm{Cu}^{2+}, \mathrm{Ni}^{2+}$ and $\mathrm{Co}^{2+}$ ions, respectively for $22 \mathrm{~cm}$ packing height, $3.8 \mathrm{~cm}^{3} / \mathrm{min}$ flow rate and $150 \mathrm{mg} / \mathrm{dm}^{3}$ initial ion concentration (Fig. 3). The breakthrough capacity of the column was $6.1 \mathrm{mg} \mathrm{Cu}$

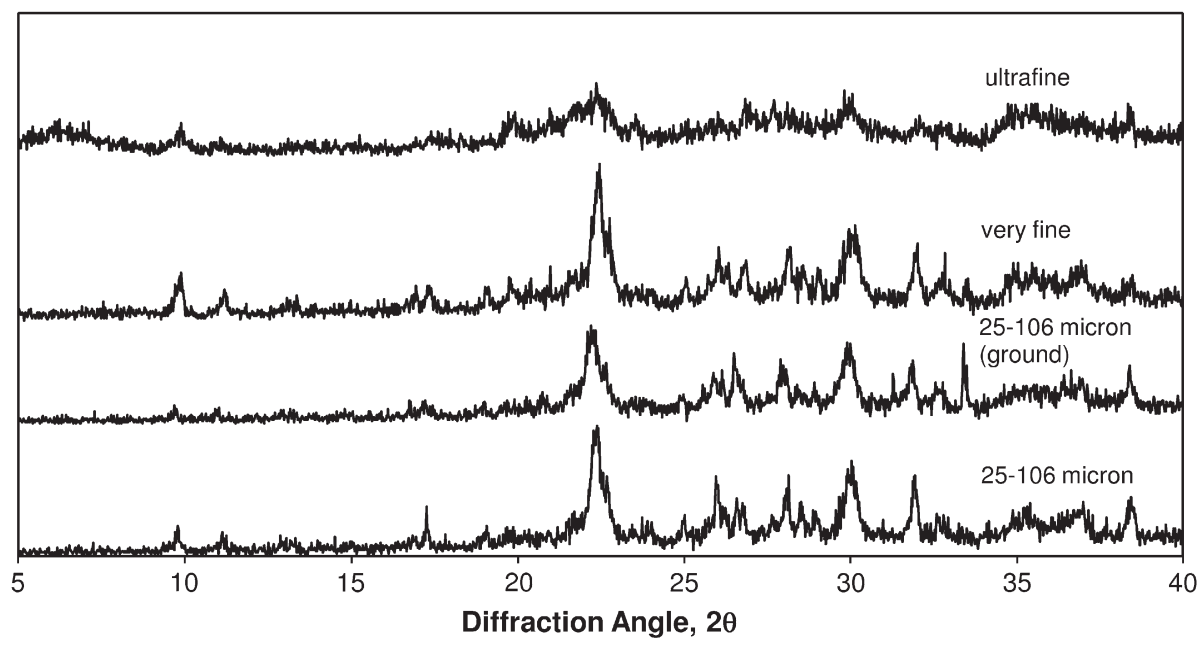

Fig. 1. X-ray diffraction diagrams of the tuff with different particle sizes. Vertical axis is diffraction intensity. 


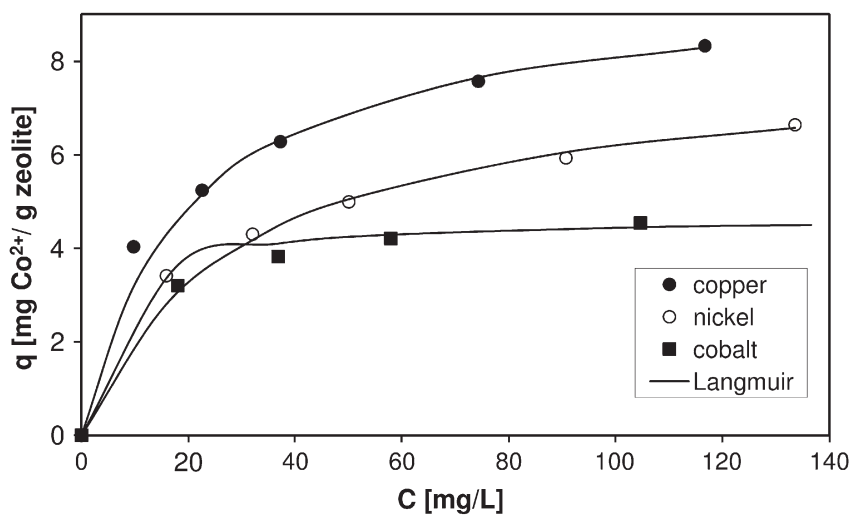

Fig. 2. Equilibrium uptake isotherm of different metals with the zeolitic tuff and the corresponding Langmuir model fits.

(II)/g, $2.9 \mathrm{mg} \mathrm{Ni(II)/g}$ and $2.9 \mathrm{mg} \mathrm{Co(II)} \mathrm{g} \mathrm{under} \mathrm{these} \mathrm{operating}$ conditions. As was also understood from the batch studies, the ion exchange capacity of the zeolitic tuff towards $\mathrm{Cu}^{2+}$ was much higher than $\mathrm{Ni}^{2+}$ and $\mathrm{Co}^{2+}$ ions. It can be seen that, the breakthrough times for $\mathrm{Co}^{2+}$ and $\mathrm{Ni}^{2+}$ are nearly the same and the system has reached the saturation point $\left(C / C_{0} \approx 1\right)$ at about 500 min for these ions. However, it took longer time for the system to reach equilibrium for $\mathrm{Cu}^{2+}$ ion, which was around 2000 min. The ion exchange capacities at column saturation were calculated by integrating the area above the breakthrough curves as $8.04 \mathrm{mg} \mathrm{Cu}^{2+} / \mathrm{g}$ tuff, $6.22 \mathrm{mg} \mathrm{Ni}^{2+} / \mathrm{g}$ tuff and $5.24 \mathrm{mg} \mathrm{Co}^{2+} / \mathrm{g}$ tuff.

In order to see the effect of packing height on column performance of the zeolitic tuff, a lower flow rate was chosen, which is $1.87 \mathrm{~cm}^{3} / \mathrm{min}$. Since decreasing flow rate increases contact time between the metal solution and the zeolitic tuff particles, more clear results were expected. For this, three experiments were conducted by using the copper nitrate solutions having the same concentration, $200 \mathrm{mg} / \mathrm{dm}^{3}$, which were passed through the column with 12.5, 18.75 and $25 \mathrm{~cm}$ packing heights. As can be seen from Fig. 4, breakthrough curves shifted to the right with increasing packing height. The breakthrough time was 50, 180 and $330 \mathrm{~min}$ corresponding $0.66,2.4$ and $4.4 \mathrm{mg} \mathrm{Cu}(\mathrm{II}) / \mathrm{g}$ breakthrough capacity for $12.5,18.75$ and $25 \mathrm{~cm}$ packing heights.

It is seen from the Fig. 4 that, increasing packing height increases the time for the system to reach equilibrium, $C / C_{\mathrm{o}} \approx 1$. After $600 \mathrm{~min}$, the column with $12.5 \mathrm{~cm}$ of packing height reached the saturation point, while 1200 and 1700 min were required to reach to this point for the columns having 18.75 and $25 \mathrm{~cm}$ packing heights, respectively. Also, it is seen that increasing packing height from $12.5 \mathrm{~cm}$ to $18.75 \mathrm{~cm}$ increased the breakthrough time by $66 \%$ and operating

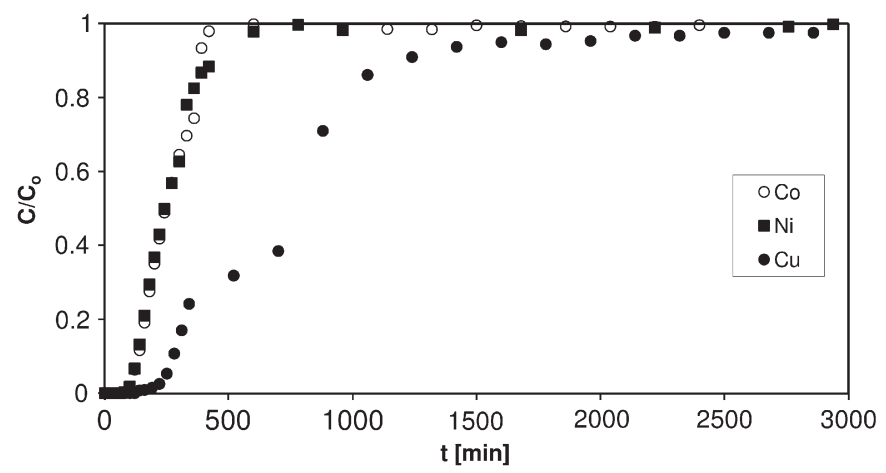

Fig. 3. Comparison of the breakthrough curves for $\mathrm{Cu}^{2+}, \mathrm{Ni}^{2+}$ and $\mathrm{Co}^{2+}$ exchange on the tuff with respect to concentration ratio and time at $30{ }^{\circ} \mathrm{C}$ (packing height $=22 \mathrm{~cm}$, flow rate $=3.8 \mathrm{~cm}^{3} / \mathrm{min}$, initial ion concentration $\left.=150 \mathrm{mg} / \mathrm{dm}^{3}\right)$.

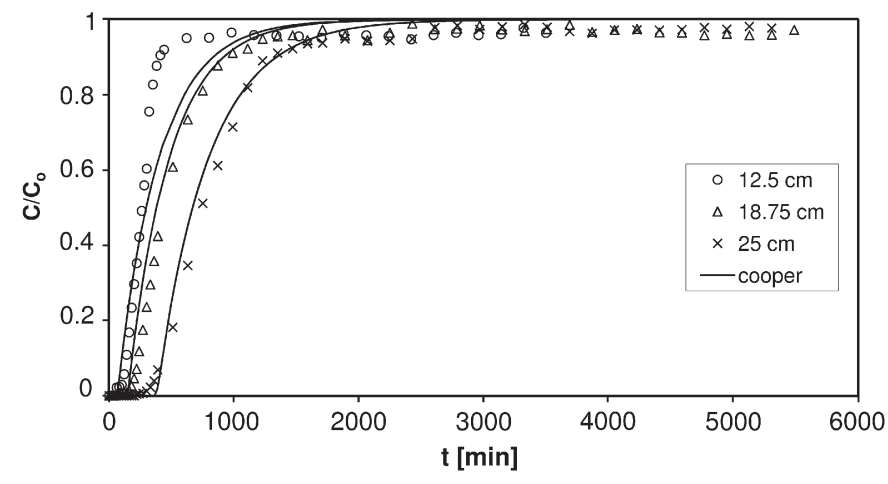

Fig. 4. Breakthrough curves for $\mathrm{Cu}^{2+}$ exchange on the tuff and corresponding model fits with respect to concentration ratio and time at $30{ }^{\circ} \mathrm{C}$ with varying packing heights (flow rate $=1.87 \mathrm{~cm}^{3} / \mathrm{min}$, initial $\mathrm{Cu}^{2+}$ concentration $=200 \mathrm{mg} / \mathrm{dm}^{3}$ ).

capacity 5\%, while increasing packing height from $18.75 \mathrm{~cm}$ to $25 \mathrm{~cm}$ was increased the breakthrough time by $80 \%$ and operating capacity $20 \%$.

In Fig. 4, the superposition of experimental results and theoretical calculated breakthrough curves constructed according to the Cooper model in Eqs. (5)-(8). Effective mass transfer coefficient, $k$ was determined as $5 \times 10^{-5} \mathrm{~s}^{-1}$ using experimental data and Cooper model. For lower packing height, the correlation between the experimental and the predicted values deviated slightly. Correlation coefficients were calculated as $0.96,0.99$ and 0.99 for increasing packing heights. Cooper model can be used in zeolitic tuff packed column design for long packing heights, since it described the breakthrough behavior of the system reasonably well.

\section{Conclusions}

The clinoptilolite content of the tuff was determined as $64 \%$ using (RIR) reference intensity ratio method. The tuff was examined to evaluate its ion exchange performance for the removal of copper, nickel and cobalt ions by performing both batch and packed column experiments at $30^{\circ} \mathrm{C}$. The copper, nickel and cobalt exchange capacities of the tuff were determined as $8.3 \mathrm{mg}(0.26 \mathrm{meq}) \mathrm{Cu}^{2+} / \mathrm{g}, 6.6 \mathrm{mg}$ (0.23 meq) $\mathrm{Ni}^{2+} / \mathrm{g}$ and $4.5 \mathrm{mg}(0.15 \mathrm{meq}) \mathrm{Co}^{2+} / \mathrm{g}$, respectively.

Breakthrough capacity and ion exchange capacity of natural zeolites were also measured. Increasing packing height increases the time for the system to reach equilibrium, $C / C_{0} \approx 1$. The ion exchange capacities at column saturation were calculated as $8.04 \mathrm{mg} \mathrm{Cu}{ }^{2+} / \mathrm{g}$ tuff, $6.22 \mathrm{mg} \mathrm{Ni}{ }^{2+} / \mathrm{g}$ tuff, $5.24 \mathrm{mg} \mathrm{Co}^{2+} / \mathrm{g}$ tuff, which were consistent with the capacities determined from batch experiments. As was also understood from the batch studies, the packed column experiments showed that the ion exchange capacity of the zeolitic tuff towards $\mathrm{Cu}^{2+}$ was greater than $\mathrm{Ni}^{2+}$ and $\mathrm{Co}^{2+}$ ions.

Cooper model for solid diffusion controlled process was applied to the system in order to investigate the dynamic behavior of the system. As a result of this simulation, breakthrough was well predicted.

This study showed that the local zeolitic tuff can be used for the removal of $\mathrm{Cu}(\mathrm{II}), \mathrm{Ni}(\mathrm{II})$ and $\mathrm{Co}(\mathrm{II})$ ions from aqueous solutions.

\section{Acknowledgments}

This study was supported by the Turkish State Planning Project (98K122130). We are grateful to the late Professor F. Mumpton for kindly providing clinoptilolite standards. We thank Dr. Mehmet Polat, H. Demir, B. Cansever, G. Narin, Y. Akdeniz for their contribution in preparation of the representative samples. 


\section{References}

[1] V.J. Inglezakis, M.D. Loizidou, H.P. Grigoropoulou, Equilibrium and kinetic ion exchange studies of $\mathrm{Pb}^{2+}, \mathrm{Cr}^{3+}, \mathrm{Fe}^{3+}$ and $\mathrm{Cu}^{2+}$ on natural clinoptilolite, Water Research 36 (2002) 2784-2792.

[2] Natural Zeolites, in: G.V. Tsitsishvili, T.G. Andronikashvili, G.N. Kirov, L.D. Filizova (Eds.), Ellis Horwood, New York, 1992.

[3] T. Armbruster, P. Simoncic, N. Döbelin, A. Malsy, P. Yang, $\mathrm{Cu}^{2+}$-acetate and $\mathrm{Cu}^{2+}$ ammine exchanged heulandite: a structural comparison, Microporous and Mesoporous Materials 57 (2003) 121-131.

[4] J. Peric, M. Trgo, N.V. Medvidovic, Removal of zinc, copper and lead by natural zeolite - a comparison of adsorption isotherms, Water Research 38 (2004) 1893-1899.

[5] M.E. Argun, Use of clinoptilolite for the removal of nickel ions from water: kinetics and thermodynamics, Journal of Hazardous Materials 150 (2008) 587-595.

[6] S. Kocaoba, Y. Orhan, T. Akyuz, Kinetics and equilibrium studies of heavy metal ions removal by use of natural zeolite, Desalination 214 (2007) 1-10.

[7] G. Kocasoy, V. Sahin, Heavy metal removal from industrial waste water by clinoptilolite, Journal of Environmental Science and Health, Part A 42 (2007) 2139-2146.

[8] M.A. Stylianou, V.J. Inglezakis, K.G. Moustakas, S.P. Malamis, M.D. Lozidou, Removal of $\mathrm{Cu}(\mathrm{II})$ in fixed bed and batch reactors using natural zeolite and exfoliated vermiculate as adsorbents, Desalination 215 (2007) 133-142.

[9] M. Sprynskyy, B. Buzewski, A.P. Terzyk, J. Namiesnik, Study of the selection mechanism of heavy metal $\left(\mathrm{Pb}^{2+}, \mathrm{Cu}^{2+}, \mathrm{Ni}^{2+}\right.$ and $\left.\mathrm{Cd}^{2+}\right)$ adsorption on clinoptilolite, Journal of Colloid and Interface Science 304 (2006) 21-28.

[10] Y. Akdeniz, S. Ulku, Thermal stability of Ag-exchanged clinoptilolite mineral, Journal of Thermal Analysis and Calorimetry 94 (2008) 703-710.

[11] S.J. Chipera, D.L. Bish, Multi-reflection RIR and intensity normalizations for quantitative analyses: applications to feldspars and zeolites, Powder Diffraction 10 (1995) 47-55.
[12] S. Ülkü, Heat and Mass Transfer in Adsorbent Beds, Convective Heat and Mass Transfer in Porous Media, 196, Kluwer Academic Pub., Dordrecht, 1991, pp. 695-724.

[13] D.M. Ruthven, Principles of Adsorption Processes, John Wiley and Sons, New York, 1984.

[14] Can Ö, Ion Exchange in Natural Zeolite Packed Column, M.S. Thesis, Izmir Institute of Technology, 2004

[15] B. Krajewska, Diffusion of metal ions through gel chitosan membranes, Reactive and Functional Polymers 47 (2001) 37-47.

[16] D. Caputa, B. de Gennaro, B. Liguori, M. Pansini, C. Collela, Adsorption properties of clinoptilolite rich tuff from Thrace, NE Greece, Studies in Surface Science and Catalysis 140 (2001) 121-129.

[17] H. Baker, Characterization for the interaction of nickel(II) and copper(II) from aqueous solutions with natural silicate minerals, Desalination 244 (2009) 48-58.

[18] K.D. Mondale, R.M. Carland, F.F. Aplan, The comparative ion exchange capacities of natural sedimentary and synthetic zeolites, Minerals Engineering 8 (1995) 535-548.

[19] A. Cincotti, N. Lai, R. Orru, G. Cao, Sardinian natural clinoptilolites for heavy metals and ammonium removal: experimental and modeling, Chemical Engineering Journal 84 (2001) 275-282.

[20] M. Türkmen, Removal of heavy metals from waste waters by use of natural zeolites, M.S. Thesis, Izmir Institute of Technology, 2001.

[21] V.A. Nikashina, V.A. Tyurina, L.I. Mironova, Sorption of copper(II) ions on the sodium and the calcium form of zeolites, Journal of Chromatography 201 (1980) 107-112.

[22] Z. Guansheng, L. Xingzheng, L. Guangju, Z. Quanchang, Removal of copper from electroplating effluents (potch water) using clinoptilolite, Occurrence, Properties and Utilization of Natural Zeolites, Akademiai Kiado, Budapest, 1988, pp. 529-539.

[23] A. Langella, M. Pansini, P. Cappelletti, B. de Gennaro, M. de Gennaro, C. Colella, $\mathrm{NH}_{4}^{+}, \mathrm{Cu}^{2+}, \mathrm{Zn}^{2+}, \mathrm{Cd}^{2+}$ and $\mathrm{Pb}^{2+}$ exchange for $\mathrm{Na}^{+}$in a sedimentary clinoptilolite, North Sardinia, Italy, Microporous and Mesoporous Materials 37 (2000) 337-343. 